
\title{
25 Research Square \\ Production of cellulase by Mucor ramanniacus using submerged fermentation and its applications in biodegradation of agro-industrial waste
}

Taiwo Dorcas Ibukunoluwa

Obafemi Awolowo University

Ademakinwa Adedeji Nelson ( $\sim$ adedeji.ademakinwa@elizadeuniversity.edu.ng )

Elizade University, Nigeria https://orcid.org/0000-0001-7736-0459

\section{Zainab Adenike Ayinla}

Obafemi Awolowo University

Femi Kayode Agboola

Obafemi Awolowo University

\section{Research Article}

Keywords: Cellulase, submerged fermentation, purification, Mucor ramanniacus, agroindustrial wastes

Posted Date: March 19th, 2021

DOl: https://doi.org/10.21203/rs.3.rs-342058/v1

License: (1) (1) This work is licensed under a Creative Commons Attribution 4.0 International License.

Read Full License 


\section{Abstract}

This study was undertaken to isolate and identify a novel cellulase-producing strain from a waste site $\left(7^{\circ} 28^{\prime} 11^{\prime \prime} \mathrm{N} 4^{\circ} 31^{\prime} 24^{\prime \prime} \mathrm{E}\right)$, optimise the growth conditions, partially purify and biochemically characterise the enzyme. The potentials of the purified cellulase to hydrolyse the lignocellulosic component of some agroindustrial wastes (e.g. orange peels etc.) was also investigated.

The best cellulase-producing fungus was identified as Mucor ramanniacus and the optimum conditions for cellulase production were $\mathrm{pH}(4.5)$, inoculum size $(12 \mathrm{~mm})$, carbon and nitrogen sources were carboxymethyl cellulose and sodium nitrate respectively resulting in a specific activity of $1423 \mathrm{Units} / \mathrm{mg}$ protein. A purification fold of 1.56 and $45.37 \%$ yield were obtained after purification. The optimum pH and temperature were at 9.0 and $40^{\circ} \mathrm{C}$ respectively. The kinetic parameters were $0.63 \pm 0.495 \mathrm{mg} / \mathrm{ml}$, $20.21 \pm 11.28 \mathrm{U} / \mathrm{ml}, 1001.4 \mathrm{~s}^{-1}$ for $\mathrm{K}_{\mathrm{m}}$ and $\mathrm{V}_{\max }$ and $\mathrm{k}_{\text {cat }}$ respectively. $\mathrm{Na}^{+}, \mathrm{K}^{+}, \mathrm{Ca}^{+}$, Cysteine, $\beta-$ mercaptoethanol and SDS were activators while Tween 80 , Triton X-100 EDTA, $\mathrm{Hg}^{2+}$ and $\mathrm{Ba}^{2+}$ inhibited the enzyme. M. ramanniacus cellulase hydrolysed all agro-industrial wastes used.

The partially purified $M$. ramanniacus cellulase showed great potential in biodegradation of various lignocellulosic substrates and the biochemical characteristics exhibited makes it suitable in industrial applications.

\section{Introduction}

Cellulases are 0-glycoside hydrolases $(\mathrm{GH})(\mathrm{EC}$ 3.2.1.4), that catalyse the hydrolysis of $\beta-1$, 4-linkages or glycosidic bonds between two or more carbohydrate moieties to glucose units (Thapa et al. 2020). The complete hydrolysis can be undertaken by microorganisms (bacteria and fungi) (Lynd et al. 2002) and also by insects, molluscs, nematodes and protozoa (Watanabe and Tokuda, 2001; Roth et al. 2020) that produce enzymes known as the cellulase systems (Gusakov et al. 2007). The cellulase systems are endoglucanases (EGL) (EC 3.2.1.4), exoglucanases or cellobiohydrolases $(\mathrm{CBH})(\mathrm{EC}$ 3.2.1.91) and $\beta$ glucosidases (BGL) (EC 3.2.1.21). Endoglucanases hydrolyse accessible intramolecular $\beta$-1,4-glycosidic bonds of cellulose chains randomly to produce new chain ends; exoglucanases processively cleave cellulose chains at the reducing and non-reducing ends to release soluble cellobiose and $\beta$-glucosidases hydrolyse cellobiose to glucose (Zhang and Lynd 2004). Cellulases are synthesized during microorganisms growth on cellulosic material and they exist as membrane-bound making use of a complex called cellulosome or free in the medium depending on the type of organism in the culture media (Doi and Kosugi 2004).

Cellulase has attracted much scientific and industrial attention. Cellulases are useful in cotton processing, paper recycling, laundry, ethanol production, juice extraction, and as animal feed additives. The world attention in the field of scientific development has shifted to environmental biotechnology due to the great challenge posed by accumulation of these wastes, cellulosic materials have become difficult to handle. These solid waste materials can be hydrolyzed efficiently by some classes of fungi known as 
filamentous fungi (Wood 1992; Subramaniyan and Prema 2004). Since microbial sources of enzyme is less capital intensive, the time required for growth is very short compared to plants and animals, the mode and amount to be produced at a time can as well be manipulated by the researchers. The majority of plant biomass, including stems and leaves are composed of lignocellulose which is the most abundant renewable biomass resource on earth. Lignocellulose is a complex and tightly organized matrix of three main polymers, hemicellulose, lignin and cellulose (the major component of agricultural wastes and municipal residues)(Gautam et al. 2010). The large volumes of cellulosic waste (35-45\%) generated annually from forestry commercial, agricultural and industrial activities are less difficult to degrade and cause imbalances in the ecosystem (James and Natalie 2001).

In this study, a cellulase producing organism, Mucor ramannianus was isolated from sites of cellulosic waste deterioration. The cellulase was partially purified and its biochemical characteristics determined. The potentials of the purified cellulase in the biodegradation of agro-industrial wastes were investigated. This is the first report of cellulase production by M. ramannianus. The biotechnological and industrial potentials of the cellulase from this fungus were established.

\subsection{Materials And Methods}

\subsection{Materials}

Carboxymethyl cellulose, was obtained from Merck Millipore International, Darmstadt, Germany. Ethylenediamine tetraacetic acid (EDTA), Bovine Serum Albumin (BSA), Malt Extract Agar was obtained from Sigma-Aldrich Chemical Company Limited, St. Loius, Mo., USA. Sephacryl S-200 was obtained from Pharmacia Fine Chemicals, Uppsala, Sweden. All other chemicals and reagents were of analytical grade.

\subsection{Methods}

\subsubsection{Sample Collection, Isolation, Identification and Screening of Fungal Isolates}

Soil samples was collected from Obafemi Awolowo University waste collection point $\left(7^{\circ} 28^{\prime} 11^{\prime \prime} \mathrm{N}\right.$ $4^{\circ} 31^{\prime} 24^{\prime \prime E}$ ), lle-lfe, Osun State, Nigeria and transported to the laboratory for immediate fungal isolation. Isolation was carried out by serial dilution and pure fungal isolates were obtained.

The pure fungal isolates were identified by observing macro and micro morphological characteristics using cotton blue in lactophenol stain technique (Alexopoulos et al. 1996). The morphological characteristics were noted and used in the preliminary identification (Kasana et al. 2008; Ademakinwa et al. 2016). Fungal strains isolated from the soil sample were screened for cellulase activity by spotting on cellulose-agar plates containing: $\mathrm{NaNO}_{3}-2.0 \mathrm{~g} / \mathrm{L}, \mathrm{MgSO}_{4} .7 \mathrm{H}_{2} \mathrm{O}-0.5 \mathrm{~g} / \mathrm{L}, \mathrm{KCl}-0.5 \mathrm{~g} / \mathrm{L}, \mathrm{K}_{2} \mathrm{HPO}_{4}-1.0 \mathrm{~g} / \mathrm{L}$, $\mathrm{FeSO}_{4} .7 \mathrm{H}_{2} \mathrm{O}-0.01 \mathrm{~g} / \mathrm{L}$ and high viscosity carboxymethyl cellulose $(0.5 \% \mathrm{w} / \mathrm{v})$. Plates were incubated at room temperature for $72 \mathrm{~h}$. Thereafter, plates were flooded with iodine solution ( $1 \%$ iodine crystals and 2 $\%$ potassium iodide) and incubated for $15 \mathrm{~min}$ at room temperature (Kasana et al. 2008). Excess stain was washed off for visual observation for zone of clearance around mycelia, indicating cellulolytic 
activity. The medium composition for the submerged fermentation production of cellulase was $\mathrm{NaNO}_{3}$ $2.0 \mathrm{~g} / \mathrm{L}, \mathrm{MgSO}_{4} .7 \mathrm{H}_{2} \mathrm{O}-0.5 \mathrm{~g} / \mathrm{L}, \mathrm{KCl}-0.5 \mathrm{~g} / \mathrm{L}, \mathrm{K}_{2} \mathrm{HPO}_{4}-1.0 \mathrm{~g} / \mathrm{L}, \mathrm{FeSO}_{4} .7 \mathrm{H}_{2} \mathrm{O}-0.01 \mathrm{~g} / \mathrm{L}$ and high viscosity carboxymethyl cellulose $(0.5 \% \mathrm{~W} / \mathrm{v})$. The medium was sterilized, cooled and inoculated with the fungal agar plugs.

\subsection{Cellulase Assay}

Cellulase activity was determined by estimating the amount of reducing sugars released in the reaction mixture containing carboxymethyl cellulose and the enzyme using the modified dinitrosalicyclic acid reagent method of Miller (1959). The reaction mixture consisted $0.5 \mathrm{ml}$ of $0.1 \% \mathrm{w} / \mathrm{v}$ CMC in citrate buffer (pH 4.8) and $0.5 \mathrm{ml}$ of enzyme (Ademakinwa et al., 2019; Ademakinwa and Agboola, 2019). One unit of cellulase activity was described as the amount of enzyme that liberated reducing sugar equivalent to $1 \mu \mathrm{g}$ of glucose per minute under the specified assay conditions. The specific enzyme activity was expressed as the unit of enzyme activity per mg of protein. The protein concentration was determined by the method of Bradford (1976) using bovine serum albumin (BSA) as standard.

\subsection{Optimization of Cellulase Production}

Optimization was studied for cellulase production were studied by maintaining all factors constant except the one being studied.

\subsubsection{Effect of Incubation Period}

The effect of incubation period on cellulase production was determined by varying the incubation time. Fifty millilitres $(50 \mathrm{ml})$ of sterilized culture medium was inoculated with $12 \mathrm{~mm}$ diameter disc of $M$. ramannianus and incubated at room temperature in a shaker for 8 days. Ten milliliters samples were withdrawn at 2 days intervals and centrifuged at $4000 \times \mathrm{g}$ for $15 \mathrm{~min}$.

The supernatant served as the crude enzyme and was analysed for cellulase activity.

\subsubsection{Effect of Inoculum Size on Cellulase Production}

Inoculum sizes varying from 4-16 mm were used to determine its effect on cellulase production by the $M$. ramannianus. The agar plugs of the fungus were inoculated separately into $50 \mathrm{ml}$ of the production medium and incubated for 4 days at room temperature. The extracellular enzyme was harvested from the culture medium by filtering using muslin cheesecloth and the filtrate (clear supernatant) was used as crude enzyme which was assayed for enzyme activity and inoculum size of $4 \mathrm{~mm}$ served as the control.

\subsubsection{Optimum pH for Cellulase Production}

The optimum $\mathrm{pH}$ for the production of cellulase was determined by varying the $\mathrm{pH}$ values of the basal salt medium ranging from 4 to 7 . The clear supernatant was assayed for cellulase activity.

\subsubsection{Determination of Optimum Temperature for Cellulase Production}


The temperature optimal for cellulase production was determined by incubating the isolate in the basal medium at 30 to $60^{\circ} \mathrm{C}$ with constant agitation. The supernatants obtained were assayed for cellulase activity. The incubation temperature at $30^{\circ} \mathrm{C}$ served as the control.

\subsubsection{Effect of Nitrogen Sources on Cellulase Production}

Different nitrogen sources were investigated for their effect on cellulase production by replacing the 2.0 $\mathrm{g} / \mathrm{L} \mathrm{NaNO}_{3}$ in the basal salt medium with organic (gelatin, casein, yeast extract, beef extract and peptone) and inorganic $\left(\mathrm{KNO}_{3}, \mathrm{NH}_{4} \mathrm{NO}_{3}, \mathrm{NH}_{4} \mathrm{H}_{2} \mathrm{PO}_{4},\left(\mathrm{NH}_{4}\right)_{2} \mathrm{SO}_{4}\right.$ and $\left.\mathrm{NH}_{4} \mathrm{Cl}\right)$ nitrogen sources and sterilized at $121^{\circ} \mathrm{C}$ for $15 \mathrm{~min}$. The sterile modified media of appropriate nitrogen source was inoculated and incubated at the optimum temperature for 4 days. The content of the flasks was filtered and the supernatants obtained were assayed for cellulase activity. The medium with $\mathrm{NaNO}_{3}$ as nitrogen source served as the control.

\subsubsection{Effect of Carbon Sources on Cellulase Production}

The effect of carbon sources was studied by replacing the carboxymethylcellulose (CMC) at 1\% concentration in the Basal Salt Medium (BSM) with agro-industrial wastes (orange peel, orange bagasse, cassava peel, potato peel, pineapple peel, banana peel and plantain peel flours) as crude carbon sources and refined carbon sources (cellobiose and filter paper flour) while other media components were kept constant. The medium was adjusted to $\mathrm{pH} 5.5$ and sterilized at $121^{\circ} \mathrm{C}$ for $15 \mathrm{~min}$. This was followed by inoculation and incubation for 4 days at optimum temperature. The supernatants obtained after filtration were assayed for cellulase activity and the medium containing $\mathrm{CMC}$ as the carbon source served as the control.

\subsection{Production of Cellulase under Optimized Condition and Determination of Fungal Growth}

The enzyme production was carried out in two different $250 \mathrm{ml}$ Erlenmeyer flasks containing $50 \mathrm{ml}$ medium each. The medium was then sterilized at $121^{\circ} \mathrm{C}$ for $15 \mathrm{~min}$. The medium was cooled and then inoculated with one and half agar plugs of $12 \mathrm{~mm}$ of three days old fungus culture. The flasks were incubated at optimum temperature in a shaker for 4 days. The extracellular enzyme was harvested from the culture medium by filtering using muslin cheesecloth and the filtrate (clear supernatant) was used as crude enzyme.

\subsection{Purification of Cellulase}

The crude enzyme filtrate $(70 \mathrm{ml})$ was lyophilized by freezing under atmospheric pressure $\left(-25^{\circ} \mathrm{C}\right)$. The powdered sample obtained after lyophilisation was re-suspended in $6 \mathrm{ml}$ of $0.1 \mathrm{M}$ citrate buffer. Preswollen Sephacryl S-200 was packed into a $1.5 \times 65 \mathrm{~cm}$ column as described by (Amiola et al., 2018 and Ademakinwa and Agboola, 2020). Five millilitres of the re-suspended lyophilized enzyme was layered on the column. The column was eluted with $200 \mathrm{ml} 0.1 \mathrm{M}$ citrate buffer, $\mathrm{pH} 4.8$. Fractions of $5 \mathrm{ml}$ were collected from the column at a flow rate of $20 \mathrm{ml} / \mathrm{h}$. Protein content of the fractions was monitored 
spectrophotometrically at $280 \mathrm{~nm}$ and the fractions were also assayed for cellulase activity. The active fractions were pooled, assayed and protein concentration was determined by methods described by Bradford (1976). The pooled enzyme was stored on ice.

The percentage yield was calculated thus:

$\frac{\text { Total Activity of Purified Enzyme }}{\text { Total Activity of Crude Enzyme }} \times 100$

The purification fold was calculated thus:

Specific Activity of Purified Enzyme

Specific Activity of Crude Enzyme

\subsection{Characterization of M. ramannianus Cellulase (MrC)}

\subsubsection{Determination of Apparent Molecular Weight}

The apparent molecular weight of the purified $\mathrm{MrC}$ was determined on the gel filtration column according to Andrews, (1964) using pre-swollen Sephacryl S-200 resin packed into $(1.5 \times 65 \mathrm{~cm})$ column (Amiola et al., 2018; Ademakinwa and Agboola, 2019). The column was calibrated with four standard proteins which included lysozyme (14 kDa; $15 \mathrm{mg} / \mathrm{ml})$, pepsin (35 kDa; $10 \mathrm{mg} / \mathrm{ml})$, ovalbumin (45 kDa; $10 \mathrm{mg} / \mathrm{ml})$ and bovine serum albumin $(66 \mathrm{kDa} ; 10 \mathrm{mg} / \mathrm{ml})$.

\subsubsection{Determination of Subunit Molecular Weight}

Sodium dodecyl sulphate polyacrylamide gel electrophoresis (SDS-PAGE) was carried out according to the method of Weber and Osborn (1975) using Tris-glycine buffer system to determine subunit molecular weight. The sample was prepared by mixing aliquots of the enzyme with electrophoresis sample buffer (60 mM Tris-HCl buffer, pH 6.8, containing 2\% SDS, 0.5 M 2-mercaptoethanol and 0.05\% bromophenol blue (a tracking dye) in ratio 2:1. SDS-PAGE was performed on $12 \%$ resolving or separating gel and $4 \%$ stacking gel.

\subsubsection{Determination of Kinetic Parameters}

The apparent kinetic parameters $\left(K_{\mathrm{M}}, \mathrm{V}_{\text {max }}, k_{\text {cat }}\right.$ and $\left.k_{\text {cat } /} K_{\mathrm{M}}\right)$ of cellulase were determined by varying concentrations of carboxymethyl cellulose (CMC) between $0.1 \mathrm{mg} / \mathrm{ml}$ and $0.5 \mathrm{mg} / \mathrm{ml}$ in $0.1 \mathrm{M}$ citrate buffer, $\mathrm{pH} 4.8$ and measuring the initial velocities $(\mathrm{U} / \mathrm{ml} / \mathrm{min})$ at a fixed volume of the purified enzyme. The assay mixture contained $0.5 \mathrm{ml}$ of purified enzyme. The data were plotted according to LineweaverBurk (1934).

\subsubsection{Effect of Temperature on Enzyme Activity and Stability}


The effect of temperature on the activity of the purified cellulase was studied over a temperature range of $20-90^{\circ} \mathrm{C}$ to determine the optimum temperature. The thermal stability of the enzyme was studied by pre-incubating the purified enzyme at the optimum temperature for $1 \mathrm{~h}$. From the incubated solution, 0.2 $\mathrm{ml}$ of the enzyme was withdrawn at 10 min interval and added to the substrate containing $0.1 \% \mathrm{CMC}$ in $0.1 \mathrm{M}$ citrate buffer to initiate the reaction and then activity was determined under standard assay conditions.

\subsubsection{Effect of $\mathrm{pH}$ and $\mathrm{pH}$ Stability}

The activity of cellulase was monitored at different $\mathrm{pH}$ values $3.0-11.0$ by incubating the mixture of the enzyme and the substrate in the presence of the appropriate buffers. The buffer systems used were 50 $\mathrm{mM}$ acetate buffer ( $\mathrm{pH}$ 3.0-5.0), $50 \mathrm{mM}$ citrate buffer ( $\mathrm{pH}$ 4.0-6.0), $50 \mathrm{mM}$ Tris buffer ( $\mathrm{pH}$ 7.0-9.0) and 50 $\mathrm{mM}$ borate buffer ( $\mathrm{pH}$ 9.0-11.0). The stability was determined by incubating aliquots of the purified enzyme in $50 \mathrm{mM}$ Tris buffer $\mathrm{pH} 9.0$ for $1 \mathrm{~h}$ at room temperature $\left(24 \pm 2{ }^{\circ} \mathrm{C}\right)$ which was withdrawn at 10 min intervals for assay.

\subsubsection{Effect of Salts}

The behaviour of the purified enzyme in the presence of metal ions in salts of chloride ions were studied in final concentrations of $1 \mathrm{mM}, 5 \mathrm{mM}$ and $10 \mathrm{mM}$. The enzyme was incubated for $30 \mathrm{~min}$ with the chloride salts and the activity was checked under optimal assay conditions. The activity was considered $100 \%$ in the absence of any salt.

\subsubsection{Effect of Inhibitors}

The effect of some representative inhibitory compounds such as EDTA, SDS, L-cysteine, Tween 80, Triton $X-100$ and $\beta$-mercaptoethanol were examined in final concentrations of $1.0 \mathrm{mM}, 2.5 \mathrm{mM}, 5.0 \mathrm{mM}$ and 7.5 $\mathrm{mM}$. Aliquots of the inhibitor was incorporated into a $1 \mathrm{ml}$ reaction mixture containing $0.2 \mathrm{ml}$ substrate solution ( $0.1 \% \mathrm{CMC}$ in $0.1 \mathrm{M}$ citrate buffer, $\mathrm{pH} 4.8$ ), $0.2 \mathrm{ml}$ buffer and $0.4 \mathrm{ml}$ water. The reaction was initiated by the addition of $0.2 \mathrm{ml}$ enzyme and incubated for $30 \mathrm{~min}$ at room temperature. The residual enzyme activity was assayed by measuring the amount of reducing sugars released and reaction mixtures without inhibitor were taken as control with $100 \%$ activity.

\subsubsection{Effect of Organic Solvents}

The purified enzyme was incubated in different organic solvent (diethyl ether, hexane, toluene, ethanol, methanol and acetone) in final concentrations of $1.0 \%, 5.0 \%, 10 \%$ and $20 \%$ for $30 \mathrm{~min}$. The relative cellulase activity was estimated against the control in which solvent was not present.

\subsubsection{Activities of MrC with various Natural Substrates}

The hydrolytic potential of purified $\mathrm{MrC}$ was investigated against a variety of substrates such as agroindustrial wastes (orange peel, orange bagasse, cassava peel, potato peel, pineapple peel, banana peel 
and plantain peel flours) as crude carbon sources, cellobiose and $\mathrm{CMC}$ as refined carbon sources. Each substrate $(0.1 \% \mathrm{w} / \mathrm{v})$ was suspended in of $0.1 \mathrm{M}$ citrate buffer, $\mathrm{pH} 4.8$. To $0.2 \mathrm{ml}$ of the substrate, $0.2 \mathrm{ml}$ of the enzyme was added to initiate the reaction which was then incubated for $30 \mathrm{~min}$ at room temperature. The relative enzyme activity was assayed by measuring the amount of reducing sugars released and expressed as percentage relative activity.

\subsection{Statistical Analysis}

Data were expressed as mean \pm standard error of mean (SEM). The significance of the results was evaluated using analysis of variance (ANOVA). Values of $p<0.05$ were regarded as statistically significant.

\subsection{Discussion}

Degradation of cellulosic materials is a complex process requiring participation by a number of microbial enzymes. This study showed that, of the eleven fungal strains were isolated from the dumpsite soil, eight had potential for cellulase production from which the best cellulase-producing strain was selected for further study. Based on morphological characterization, the organism was identified as Mucor ramannianus. Cellulases have been identified in a variety of fungal species such as Trichoderma sp., Penicillium sp. and Aspergillus sp. (Lakshmikant and Mathur 1990; Mandels and Reese 1985).

Eleven (11) fungal strains were isolated from the University dumpsite soil. Eight (8) out of the eleven (11) fungal strains isolated showed a zone of clearance with varying magnitude indicating the production of the enzyme and Mucor ramannianus which had the highest activity was selected for further studies. Aside from M. ramannianus, another notable fungus that elaborated cellulase was Aureobasidium pullulans (Table 1 a). The production of cellulase by A. pullulans has been reported by Ademakinwa and Agboola et al. (2019). From our previous studies, this fungus can also elaborate rhodanese (Ademakinwa et al., 2020), laccase (Ademakinwa et al., 2016) and fructosyltransferase (Ademakinwa et al. 2018). The isolates were further tested for cellulolytic activity in the culture broth using CMC as substrate (Table 1 a $\&$ b). The production of enzyme gradually increased with the fermentation (incubation) time and reached the peak point on the $4^{\text {th }}$ day of incubation. The inoculum size of $12 \mathrm{~mm}$ resulted in a relatively higher cellulase activity $\left(61.38 \mathrm{U} / \mathrm{mg}\right.$. Maximum cellulase production was obtained the temperature of $40^{\circ} \mathrm{C}$ with $124.53 \mathrm{U} / \mathrm{mg}$ in the temperature range tested (graphs not shown).

The optimum temperature for growth of fungus may not necessarily be the optimum temperature for production of enzymes, although incubation temperature is a critical factor in enzyme production (Kheng and Omar 2005). This study recorded an optimum temperature for maximum enzyme production at $40^{\circ} \mathrm{C}$ with specific activity of $134.16 \mathrm{U} / \mathrm{mg}$ protein following a significant decline in cellulase production as temperature increased. Sabu et al. (2002) reported that as temperature increases, enzyme production decreases because enzyme is a secondary metabolite produced during exponential growth phase and incubation at high temperature could lead to poor growth and thus a reduction in enzyme yield. 
The result for the cellulase production at $40^{\circ} \mathrm{C}$ is in accordance with previous findings for Aspergillus terreus QTC 828 (Ali et al. 1991), Aspergillus flavus (Lin et al. 2010) and Aspergillus fumigatus (Sherief et al. 2010). In contrast, Asquieri and Park (1992) reported that the optimum temperature for maximum cellulase production from thermostable Aspergillus sp. was $37^{\circ} \mathrm{C}$. Padmavathi et al. (2012) also observed a good enzyme yield with Mucor plumbeus at $37^{\circ} \mathrm{C}$.

In this study, the optimum $\mathrm{pH}$ of the medium was 4.5. Among the physical parameters, utilization of $\mathrm{pH}$ in growth medium is considered an important factor during enzyme production by inducing morphological changes in microbes and in enzyme secretion. According to Silva et al. (2009), most filamentous fungi are $\mathrm{pH}$ dependent. The $\mathrm{pH}$ change observed during the growth of microbes also affects product stability in the medium (Gupta et al. 2003). Padmavathi et al. (2012) reported a pH optimum of 3.0 for Mucor plumbeus, while Bhaskar et al. (2014) reported an optimum pH of 5.0 for maximum cellulase production by Penicillium variabile. Beldman et al. (1985) also reported that Aspergillus species grow and metabolize well in acidic $\mathrm{pH}$ medium between $\mathrm{pH} 3.0$ - 5.0. Most fungal cultures prefer a slightly acidic $\mathrm{pH}$ medium for growth and enzyme biosynthesis (Haltrich et al. 1996) which agrees with the result obtained in this study. It is noteworthy to highlight that the specific activity was albeit lower during the optimization of the effect of $\mathrm{pH}$ compared with the values obtained during temperature optimization. This might be attributed to the physiological change that the fungus, $M$. ramannianus exhibits at altered $\mathrm{pH}$ values

Research has shown that enzyme synthesis is correlated with the quality and concentration of nitrogen and carbon sources. These requirements differ from one organism to another (Pandey et al. 2001; Schnurer and Jarvis 2010). Maximum cellulase production (31.99 U/mg protein) was observed with sodium nitrate $\left(\mathrm{NaNO}_{3}\right)$ followed by potassium nitrate $\left(\mathrm{KNO}_{3}\right)$ with activity of $19.32 \mathrm{U} / \mathrm{mg}$ protein although an enzyme production of about $25 \mathrm{U} / \mathrm{ml}$ was obtained in Aspergillus terreus KJ829487 (Olanbiwonninu and Odunfa, 2016). Inorganic nitrogen source in the form of diammonium hydrogen phosphate $\left(\mathrm{NH}_{4} \mathrm{H}_{2} \mathrm{PO}_{4}\right)$, failed to support cellulase production as it inhibited the growth of Mucor ramannianus unlike Aureobasidium pullulans isolates Ap20 and Ap33 which grew and produced enzyme with specific activity of 9.24 and $12.81 \mathrm{U} / \mathrm{mg}$ protein/h respectively (Kudanga and Mwenje, 2005). Although ammonium sulphate $\left(\left(\mathrm{NH}_{4}\right)_{2} \mathrm{SO}_{4}\right)$, ammonium nitrate $\left(\mathrm{NH}_{4} \mathrm{NO}_{3}\right)$ and ammonium chloride $\left(\mathrm{NH}_{4} \mathrm{Cl}\right)$ gave specific activity of $3.29,1.21,2.19 \mathrm{U} / \mathrm{mg}$ protein respectively. This is very low compared to $\mathrm{NaNO}_{3}$ in this study. Many studies have reported that ammonium compounds are the most favourable nitrogen sources for protein and cellulase synthesis. Sethi and Gupta (2014) reported ammonium sulphate as the best nitrogen source for Aspergillus niger.

This study found that gelatin, casein and peptone were poor sources of nitrogen for the production of cellulase by Mucor ramannianus while beef extract and yeast extract are best and second-best organic source of nitrogen. Mrudula and Murugammal, (2011) reported that peptone supported maximum enzyme production followed by beef extract, groundnut oilcake, yeast extract and casein in Aspergillus niger. Many researchers have reported good cellulase production with organic nitrogen sources but results from this study contradict that, clearly indicating that inorganic nitrogen sources are preferred by 
Mucor ramannianus to organic ones for cellulase production which may be due to the inability of the organism to hydrolyse the organic nitrogen sources during growth and enzyme production as opposed to other inorganic nitrogen sources. Thus, variability in the preference for nitrogen source could be explained by strain difference.

The study of the effect of carbon sources on the production of cellulase by Mucor ramannianus revealed that carboxymethylcellulose was the best with specific activity of 592.06 Unit/mg, thus enhancing both nutrient uptake and the release of enzymes into culture medium. This result was also in agreement with Gomathi et al. (2012) and Sajith et al. (2014), where both authors reported carboxymethylcellulose as the best source of carbon for the strains of Aspergillus sp.

Endoglucanase, $\beta$-glucosidase and exoglucanase activities were tested using CMC, cellobiose and filter paper strips as substrates for assay and as the sole carbon source for the culture medium respectively. Endoglucanase activity $(592.06 \mathrm{U} / \mathrm{mg})$ was higher than exoglucanase activity $(110.30 \mathrm{U} / \mathrm{mg})$ possibly because it is believed to be the rate-limiting activity(Mandels 1982; Enari 1983). Specific activity of 55.99 $\mathrm{U} / \mathrm{mg}$ protein by Mucor ramannianus cellulase using cellobiose as carbon source showed $\beta$-glucosidase activity which means that the isolate is capable of carrying out complete cellulase hydrolysis. This shows appreciable levels of enzyme activity on both carboxymethylcellulose and filter paper when compared with the levels obtained for Aureobasidium pullulans Ap33 and Ap20 (Kudanga and Mwenje 2005) and cellulase from A. pullulans NAC8 (Ademakinwa and Agboola, 2019).

Shankar and Isaiarasu (2011) showed that agro-industrial wastes are considered best for enzyme production. Some newly developed agro-industrial wastes such as orange peel, orange bagasse, cassava peel, potato peel, pineapple peel, banana peel and plantain peel flours which were used in this study as sole carbon source (added at $1 \%(\mathrm{w} / \mathrm{v})$ to the growth medium) for cellulase production gave little or no activity when compared to CMC. Cassava and potato peel flours gave no enzyme activity while plantain peel, pineapple peel and orange peel flours gave activities of $91.17,86.05$ and $74.02 \mathrm{U} / \mathrm{mg}$ protein respectively which can still be used as low-cost materials for production of cellulase from Mucor ramannianus. Carbon sources therefore serve as important substrates for energy production (Shankar and Isaiarasu 2011). Thus, the type of strain, culture conditions, nature of the supplement and availability of nutrients are the important factors affecting enzyme production by microbes (Salihu and Aman 2012).

Production of the crude cellulase was subsequently carried out by growing the isolate in a basal salt medium containing $\mathrm{CMC}$ as the sole carbon source for 4 days after which the medium containing the crude cellulase was collected by filtering with cheese cloth.

Cellulase produced by Mucor ramannianus was purified and the physicochemical properties were investigated. The elution profile on Sephacryl S-200 is shown in Fig. 1. A single peak of activity was obtained with a yield of $45.37 \%$ and a purification-fold of 1.56 . Table 2 .

The purification process of the crude cellulolytic enzyme gave 1.56 -fold purification, $45.37 \%$ recovery and a specific activity of $2214.29 \mathrm{U} / \mathrm{mg}$ protein. This result agreed with that reported by Shahid et al. (2016) 
who obtained a purification-fold of $1.90,46.28 \%$ recovery and $3.51 \mathrm{U} / \mathrm{mg}$ protein. The purification fold is lower compared to cellulase purified from previous studies. For example, ljaz et al. (2014) purified cellulase by gel filtration from Aspergillus niger up to 5.71 -fold with a specific activity of $232.5 \mathrm{U} / \mathrm{mg}$. Also, an extracellular endoglucanase gave a purification fold up to 408 from Mucor circinelloides using a combination of ethanol precipitation $(75 \%, \mathrm{v} / \mathrm{v})$, ion-exchange and gel filtration chromatography (Saha 2004). Purification results differed with respect to the method applied.

The molecular weight of the native cellulase estimated by gel filtration on Sephacryl S-200 was $23.4 \mathrm{kDa}$. The molecular weight is similar to that of an endoglucanase from Mucor circinelloides whose molecular weight was $25000 \mathrm{Da}$ and $27000 \mathrm{Da}$ as estimated by gel filtration and SDS-PAGE respectively (Saha 2004). The purified cellulase from Aspergillus niger resolved on SDS-PAGE was found to be a homogenous monomeric protein as evident by a single band corresponding to $43 \mathrm{kDa}$ (ljaz et al. 2014). Sajith et al. (2014) reported that the molecular weight of the cellulase produced by Aspergillus flavus BS1 is about $23 \mathrm{kDa}$, which is similar to the result of this study although the partially purified enzyme from a strain of Aspergillus flavus had a molecular weight of approximately $30.2 \mathrm{kDa}$ (Ajayi et al. 2007). Devi and Kumar (2012) reported that the apparent molecular weights of the cellulase isoforms produced by Aspergillus niger were 33 and $24 \mathrm{kDa}$ while Cole (1980) reported values within the range of 20 to $60 \mathrm{kDa}$ for cellulase from different cellulolytic organisms. The molecular weight of the single cellulase from $M$. ramannianus described in this study is very much comparable to these cellulases.

The Michaelis-Menten constant $\left(K_{\mathrm{M}}\right)$ and maximum reaction velocities $\left(\mathrm{V}_{\text {max }}\right)$ values of $\operatorname{MrC}$ were $0.63 \pm$ $0.15 \mathrm{mg} / \mathrm{ml}$ and $20.21 \pm 1.28 \mathrm{U} / \mathrm{ml}$ respectively. The value of $K_{\mathrm{M}}$ obtained in this study was low showing greater affinity for carboxymethyl cellulose as compared to some other studies with a bit higher $K_{\mathrm{M}}$ values of $3.6 \mathrm{mg} / \mathrm{ml}, 1.90 \mathrm{mg} / \mathrm{ml}, 1.481 \mathrm{mg} / \mathrm{mL}$ and $1.167 \mathrm{mg} / \mathrm{ml}$ as reported by (Bakare et al. 2005; Tokuda and Watanabe 2007; Bai et al. 2017; Quadri et al. 2017) respectively. The $K_{\mathrm{M}}$ of cellulase from Aspergillus niger and Rhizopus sp. was reported as $1.3 \mathrm{mg} / \mathrm{ml}$ and $1.0 \mathrm{mg} / \mathrm{ml}$ respectively (Ogwuche et al. 2012) which is a little close to the $K_{\mathrm{M}}$ obtained in this study. The $\mathrm{V}_{\max }$ obtained in this study is greater than the values $0.0833 \mu \mathrm{g}$ of glucose $/ \mathrm{mL} / \mathrm{min}$ and $5.37 \mu \mathrm{g} / \mathrm{mL} / \mathrm{min}$ reported by (Quadri et al. 2017; Kumar et al. 2012) respectively but lower than the $V_{\text {max }}$ values of cellulase from Aspergillus niger given as $45.5 \mathrm{U} / \mathrm{mL}$ (ljaz et al. 2014). $K_{m}$ is equivalent to the substrate concentration at which the reaction rate is half maximal and is often used as an indicator of the affinity of an enzyme for its substrate (Nelson and Coxx 2004), a high $K_{\mathrm{M}}$ indicates weak binding, that is, low affinity of the enzyme for the substrate while a low $K_{\mathrm{M}}$ indicates strong binding that is high affinity of the enzyme for the substrate (Berg et al. 2002). The maximal rate, $V_{\text {max }}$, reveals the turnover number of an enzyme, which is the number of substrate molecules converted into product by an enzyme molecule in a unit time when the enzyme is fully saturated with substrate (Berg et al. 2002).

The turnover number, $k_{\text {cat }}$, for M. ramannianus cellulase was $1001.04 \mathrm{~s}^{-1}$ which is greater than earlier report of $1556.11 \mathrm{~min}^{-1}$ and $1475 \mathrm{~min}^{-1}$ (Salem et al. 2008; Shahid et al. 2016). The catalytic efficiency, $\mathrm{k}_{\mathrm{cat}} / K_{\mathrm{M}}$ is the rate constant for the interaction of substrate and enzyme and can be used as a measure of 
catalytic efficiency, to know how efficient an enzyme converts a substrate into product. The $k_{\text {cat }} / K_{\mathrm{M}}$ obtained for $M$. ramannianus cellulase was $1.59 \times 10^{3} \mathrm{M}^{-1} \mathrm{~s}^{-1}$ which is lower than the value $\left(1.3 \times 10^{6} \mathrm{M}^{-}\right.$ ${ }^{1} \mathrm{~s}^{-1}$ ) earlier reported for Bacillus megaterium cellulase Shahid et al. 2016). Enzymes that have $k_{\text {cat }} / K_{\mathrm{M}}$ ratios at the upper limits $\left(10^{8}\right.$ and $\left.10^{9} \mathrm{M}^{-1} \mathrm{~s}^{-1}\right)$ are said to have achieved catalytic perfection (Berg et al. 2002; Nelson and Coxx 2004) In order to convert substrate into product, temperature plays a vital role as enzyme has to collide and bind with the substrate at the active sites. A gradual increase was observed in the activity with increase in temperature up to $40^{\circ} \mathrm{C}$ (Fig. 2). An optimum temperature of $40^{\circ} \mathrm{C}$ was obtained for cellulase from $M$. ramannianus and at higher temperature above the optimum, enzyme activity decreased due to thermal denaturation (that is enzyme decomposition). This result is the same with the optimal temperature of $40^{\circ} \mathrm{C}$ that was reported for Aspergillus niger Z10 strain (Gokhan-Coral 2002). Similarly, Otajevwo and Aluyi (2010) reported peak cellulase activity at $40^{\circ} \mathrm{C}$ for Psuedomonas aeruginosa. Temperature optimum for purified cellulase was observed at $70^{\circ} \mathrm{C}$ for Mucor circinelloides (Saha 2004). Highest activity was recorded at $50^{\circ} \mathrm{C}, 30^{\circ} \mathrm{C}$ and $60^{\circ} \mathrm{C}$ for Cellulomonas sp., $\mathrm{K}$. gibsonii CAC1 enzyme and Geobacillus sp. (Adu et al. 2015; Potprommanee et al. 2017; Bai et al. 2017) respectively. Cellulase activities from Trichoderma sp. and other mesophilic cellulolytic fungi are at their optimum when assayed at about $50^{\circ} \mathrm{C}$ (Mandels et al. 1974; Kawamori et al. 1987). The purified enzyme was quite stable at $40^{\circ} \mathrm{C}$ (optimum temperature) for $40 \mathrm{~min}$ by retaining $100 \%$ of its activity although it lost about $20 \%$ activity after 60 min of incubation time. Ogwuche et al. (2012) reported a loss of enzyme stability as temperature increased towards $70{ }^{\circ} \mathrm{C}$ for Rhizopus sp. and Aspergillus niger. Bai et al. (2017) also showed that the enzyme retains $50 \%$ activity at $60^{\circ} \mathrm{C}$ for $40 \mathrm{~min}$ of pre-incubation.

The influence of $\mathrm{pH}$ on enzyme activity was found to be an important parameter and the $\mathrm{pH}$ optima for maximum cellulase activity in this study was found to be 9.0 (Fig. 3) an alkaline pH which is similar to what was obtained from Bacillus sp. cellulase (Fukumori et al. 1985). Mucor circinelloides displayed an optimum activity at pH 5.0 (Saha 2004). Potprommanee et al. (2017) reported the highest cellulase activity at $\mathrm{pH} 7.0$ in phosphate buffer, and the enzyme was still active over a wide $\mathrm{pH}$ range while ljaz et al. (2014) reported an optimum pH 7.0 (neutral pH) for Aspergillus niger. The pH stability of cellulase was determined at optimum $\mathrm{pH}$ and this shows that the enzyme was stable as it retained about $81 \%$ of its activity for $60 \mathrm{~min}$ of incubation time which showed that the $\mathrm{pH}$ did not really influence enzyme stability after prolonged incubation. In previous reports, $\mathrm{pH}$ stability of cellulase was determined at different $\mathrm{pH}$ values and over these wide $\mathrm{pH}$ range (3-8) cellulase activity was retained after $5 \mathrm{~h}$ of incubation (Potprommanee et al. 2017). Cellulase from Mucor circinelloides is fairly stable and highly active over a broad pH range since it retained $80 \%$ activity at $\mathrm{pH} 3.0$ and also at pH 8.0 upon $30 \mathrm{~min}$ incubation (Saha 2004) . ljaz et al. (2014) also reported that cellulase was completely stable in a large pH range (5-9) for Aspergillus niger. Enzymatic activities are sensitive to changes in $\mathrm{pH}$ values and this may be due to ionic composition of the medium contributing to the stability of the enzyme.

Metal ions can be associated with proteins and can as well form complexes with other molecules linked to enzymes acting as electron donors or acceptors as Lewis's acids, or as structural regulators (Riordan 1997). These ions can either activate or inhibit the enzymatic activity by interacting with amine or

Page $12 / 28$ 
carboxylic acid group of the amino acids ((Ishida et al. 1980) and several mono-, di-, and trivalent metal ions have reported the activation or inactivation of microbial cellulases (Mandels and Reese 1965). The carboxymethyl cellulase (CMCase) activity of cellulase in this study was greatly enhanced at various concentrations of $1 \mathrm{mM}, 5 \mathrm{mM}$ and $10 \mathrm{mM}$ by Na${ }^{+}, \mathrm{K}^{+}, \mathrm{Ca}^{2+}$ but it was slightly inhibited by $\mathrm{Hg}^{2+}$ with $9.96 \%$ loss of activity at $10 \mathrm{mM}$ and completely inhibited by $\mathrm{Ba}^{2+}$ with $100 \%$ loss of activity at $5 \mathrm{mM}$ and $10 \mathrm{mM}$ as compared to control (Fig. 4). Inhibition of cellulases by heavy metals $\mathrm{Hg}^{2+}$ and $\mathrm{Ba}^{2+}$ is related to the interaction with catalytic amino acids containing sulphur such as cysteine and histidine rich residues leading to oxidation and irregular formation of disulphide bonds(Tejirian and Xu 2010), thus denature the enzyme and make them less soluble, there by precipitating them. $\mathrm{Ba}^{2+}$ can complex with arginine, glutamine, proline, serine and valine(Bush et al. 2008). This result is similar to that obtained by Potprommanee et al.(2017) which reported that CMCase activity of cellulase strongly increased in the presence of $\mathrm{CaCl}_{2}(174.32 \%)$ followed by $\mathrm{NaCl}(158.11 \%)$ and $\mathrm{KCl}(117.57 \%)$ respectively from Geobacillus sp. HTA426. Gaur and Tiwari (2015) had also reported that CMCase activity was strongly stimulated by $\mathrm{CaCl}_{2}, \mathrm{NaCl}$ and $\mathrm{KCl}$ ions from Bacillus vallismortis, although Quadri et al. (2017) reported reduced enzyme activity by $\mathrm{KCl}(36.22 \%)$ and $\mathrm{NaCl}(61.45 \%)$ from Bacillus pantothenticus. Saha (2004) reported that cellulase activity was enhanced by $8 \%$ by $\mathrm{Ca}^{2+}$ at $5 \mathrm{mM}$ by Mucor circinelloides. ljaz et al. (2014) reported that $\mathrm{Hg}^{2+}$ showed inhibitory effect on cellulase at $5 \mathrm{mM}$ for Aspergillus niger.

Activity of cellulase from $M$. ramannianus was greatly affected by a non-ionic surfactant, Tween 80 , at the various concentrations examined which might be due to the fact that this surfactant does not have the capability to modify the surface property and help to minimize the irreversible inactivation of cellulase (Wu and Ju 1998) as compared to others. On the other hand, the enzyme was moderately active in the presence of Triton X-100 at concentrations of $1.0 \mathrm{mM}$ and $2.5 \mathrm{mM}$ but averagely active as concentration increases. Sodiumdodecyl sulphate (SDS) (Fig. 5) was also found as cellulase activator at $2.5 \mathrm{mM}$ given a percentage relative activity of $142.87 \%$ when compared with control $(100 \%)$ although at higher concentrations it showed an inhibitory effect. This result partially supports the results obtained from previous studies which showed that anionic and non-ionic surfactants were found as activators of cellulase. Potprommanee [65] reported that CMCase activity increased with SDS (129.73\%), Triton X-100 (113.51\%) and Tween-80 (105.41\%). Increase in the cellulolytic activity with these surfactants has also been observed by Seki et al. (2015) and Ashaet al. (2012).

This study also reported EDTA, a metal chelating agent as inhibitory to the cellulase activity with a residual activity of $16.78 \%$ at $7.5 \mathrm{mM}$ which corresponds to the reports of Bakare et al. (2005) and ljaz et al. (2014) for cellulase from wild type of Pseudomonas fluorescens and Aspergillus niger respectively. However, Saha (2004) reported that cellulase activity was not affected by EDTA at $10 \mathrm{mM}$ for Mucor circinelloides. The observed inhibition by EDTA suggested that the cellulase has an inorganic group which forms inactive complexes with EDTA, thus, the enzyme is a metalloenzyme. CMCase activity was enhanced by L-cysteine (147.34\%), a semi-essential proteinogenic amino acid because its thiol side chain participates in enzymatic reactions as a nucleophile and $\beta$-mercaptoethanol (115.78\%) at a concentration of $7.5 \mathrm{mM}$. Gaur and Tiwari (2015) reported that $\beta$-mercaptoethanol retained full activity at $10 \mathrm{mM}$ and 
explained that $\beta$-mercaptoethanol can reduce disulphide bonds and re-nature their activity, if the oxidation or aggregation of these enzyme proteins occurs during purification and storage, thus, suggesting that the active site of the enzyme contains - SH groups.

The results of different organic solvents tested showed that the activity of cellulase was not substantially inhibited. Water miscible (ethanol, methanol, acetone) organic solvents examined in final concentrations of $1.0 \%$ to $20 \%$ (Fig. 6 ) greatly enhanced cellulase activity whereas water immiscible (hexane and toluene) organic solvent slightly inhibited the enzyme activity at $5 \%$ with residual activity of $54.89 \%$ and $90.17 \%$ respectively although diethyl ether at $5 \%$ and $10 \%$ final concentration activated the enzyme. These findings were in accordance with Bai et al. (2017) where alcohols slightly reduced the activity at a concentration of $10 \%$ with residual activity above $90 \%$. In another study, an endoglucanase residual activity of $68.6 \%, 67.4 \%, 63.6 \%$ and $78.1 \%$ were reported for methanol, ethanol, hexane and toluene respectively with obvious stimulation by acetone (127.3\%) and dimethylformamide (118.4\%) (Li and Yu 2012). Zaks and Klibanov (1988) suggested that stimulation of enzyme activity by organic solvents might be due to the residues of carried-over non-polar hydrophobic solvent providing an interphase, thereby keeping the enzyme in an open conformation resulting in stimulated activation. It is therefore evident from this study that $\mathrm{MrC}$ is stable with high activity in all the organic solvents examined at $5 \% \mathrm{v} / \mathrm{v}$ except for hexane and could be potentially useful for practical applications in biotechnological processes such as bioremediation of carbohydrate-polluted salt marshes and industrial wastewaters contaminated with organic solvents.

The activity of the purified enzyme on various natural substrates showed that cellulase was found to completely hydrolyse cellobiose, a microcrystalline cellulose and insoluble cellulosic substrates such as orange peel, orange bagasse, cassava peel, potato peel, pineapple peel, banana peel and plantain peel (each at $0.1 \%, w / v$ ) where $\mathrm{CMC}$ served as the control (Fig. 7 and Table 3). The enzyme has great potential to be used in enzymic saccharification of various lignocellulosic substrates. The higher activity of the enzyme for cellobiose (187.5\%) than CMC (100\%) infer the presence of exoglucanase and endoglucanase (Wood and Bhat 1988). Quadri et al. (2017) reported a higher value of microcrystalline cellulose than $\mathrm{CMC}$, although the other substrates investigated gave low percentage relative activities.

\section{Conclusion}

The fungus $M$. ramannianus, produced cellulolytic enzyme under optimized conditions. One-factor-at-a time based optimization allowed for improved cellulase production by the fungus. The purified enzyme displayed a relative stability in organic solvent, heat etc. and was able to biodegrade the cellulose component of some locally sourced agro-industrial wastes. The hydrolytic properties as well as catalytic potentials of the purified $\mathrm{MrC}$ makes it of potential immense biotechnological or industrial importance such as in lignocellulosic waste management

\section{Declarations}




\section{Competing interests}

The authors declare no competing interests.

\section{References}

Ademakinwa, A.N. and Agboola, F.K., 2016. Biochemical characterization and kinetic studies on a purified yellow laccase from newly isolated Aureobasidium pullulans NAC8 obtained from soil containing decayed plant matter. Journal of Genetic Engineering and Biotechnology, 14(1), pp.143-151.

Ademakinwa, A.N.; Ayinla, Z.A.; Agboola, F.K. Strain improvement and statistical optimization as a combined strategy for improving fructosyltransferase production by Aureobasidium pullulans NAC8. Journal of Genetic Engineering and Biotechnology, v. 15, p. 345-358, 2017.

Ademakinwa, A.N.; Agunbiade, M.O.; Ayinla, Z.A.; Agboola, F.K. Optimization of aqueous two-phase partitioning of Aureobasidium pullulans a-amylase via response surface methodology and investigation of its thermodynamic and kinetic properties. International Journal of Biological Macromolecules. v. 140, p. 833-841, 2019.

Ademakinwa, A.N.; Agboola, F.K. Some biochemical, catalytic, thermodynamic and kinetic properties of purified fructosyltransferase from wild and improved mutant-type Aureobasidium pullulans NAC8. Biocatalysis and Biotransformation, v. 38, p.1-12. 2020.

Ademakinwa, A.N., Agunbiade, M.O. and Fagbohun, O., 2020. Biodegradation of cyanide in cassava wastewater using a novel thermodynamically-stable immobilized rhodanese. Preparative Biochemistry \& Biotechnology, pp.1-11.

Ademakinwa, A. N., Agunbiade, M. O., Agboola, F. K.. Trilepisium madagascariense fruit-wastes as cheap feedstock for bioethanol production. Acta Biologica Szegediensis, v. 63(1),p. 45-50. 2019

Adu, K.T.; Kayode, R.M.O.; Adu, M.D. Physicochemical Characterization of Cellulase Produced from Kurthia gibsonii (CAC 1) Isolated from Cassava Dumpsites in Ibadan, Nigeria. Ethiopian Journal of Environmental Studies and Management v. 8(1), p. 738-751, 2015.

Ajayi, A.A.; Adejuwon, A.O.; Awojobi, O.K.; Olutiola, P.O. Effect of cations and chemicals on the activity of partially purified cellulase from tomato (Lycopersicon esculentum Mill) fruits deteriorated by Aspergillus flavus Linn. Pakistan Journal of Nutrition v. 6, p. 198-200, 2007.

Alexop oulos, C.J.; Mims, C.W.; Blackwell, M. Introductory Mycology, Vol 4. Wiley, New York. 1996.

Ali, S.; Sayed, A.; Sarker, R.I.; Alam, R. Factors affecting cellulase production by Aspergillus terreus using water hyacinth. World J Microbiol Biotechnol. v.7 (1), p. 62-66, 1991. 
Amiola, R.O.; Ademakinwa, A.N.; Ayinla, ZA.; Ezima, E.N.; Agboola, F.K. Purification and biochemical characterization of a $\beta$-cyanoalanine synthase expressed in germinating seeds of Sorghum bicolor (L.) moench. Turkish Journal of Biochemistry. v. 43(6), p. 638-650, 2018.

Andrews, P. Estimation of the Molecular Weights of Proteins

by Sephadex Gel-Filtration. Biochemical Journal. v. 91, p. 222-233, 1964.

Asha, B.M.; Revathi, M.; Yadav, A.; Sakthivel, N. Purification and characterization of a thermophilic cellulase from a novel cellulolytic strain, Paenibacillus barcinonensis. Journal of Microbiology and Biotechnology. $\quad$ v. 22, p. 1501-1509, 2012.

Asquieri, E.R.; Park, Y. K. Production of extracellular cellulases from the thermostable Aspergillus sp. Reviews in Microbiology. v. 23, p. 183-188, 1992.

Bai, H.; Muhammad, I.; Wang, Y.; Wang, H. Han, X. Purification and Characterization of Cellulose Degrading Enzyme from Newly Isolated Cellulomonas Sp. Cellulose Chemistry and Technology v. 51(3-4): 283-290. 2017.

Bakare, M.K.; Adewale, I.O.; Ajayi, A.; Shonukan, O.O. Purification and characterization of cellulase from the wild-type and two improved mutants of Pseudomonas fluorescens. African Journal Biotechnology v. 4, p. 898-904, 2005.

Beldman, G.; Searle-Van, L.M.F.; Rombouts, F.M.; Voragen, F.G.J. The cellulase of Trichoderma viride: Purification, characterization and comparism of all detectable endoglucanases, exoglucanases and $\beta$ glucosidase. European Journal of Biochemistry. v. 146, p. 301-308, 1985.

Benjamin, S.; Pandey, A. Candida rugosa lipases: Molecular Biology and Versatility in Biotechnology. Yeast. v. 14:1069-1087, 1998.

Berg, J.M.; Tymoczko, J.L.; Stryer, L. Biochemistry. 6th Edition. New York: W. H. Freeman, p. 220-222, 2002.

Bhaskar, C.D.; Manas, D. Pronoy, S. Production of Cellulase Enzyme by Submerged Fermentation Process from Penicilliuum variabile. Indian Journal of Applied Research in Biotechnology. v. 4: p. 42-45, 2014.

Bradford, M.M. A rapid and sensitive method for the quantitation of microgram quantities of protein utilizing the principle of protein-dye binding. Analytical Biochemistry. v. 72, p. 248-254, 1976.

Bush, M.F.; Oomens, J.; Saykally, R.J. Williams, E.R. Effects of alkaline earth metal ion complexation on amino acid zwitterion stability: Results from infrared action spectroscopy. American Journal of Chemical Society. v. 130, p. 6463-6471, 2008.

Cole, 0.0. Studies on the extracellular carbohydratases produced by bacteria from the gut of the termite Aritermes evunifer. Fellowship Thesis, Institute of Science Technology, London, pp160, 1980. 
Devi, M.C.; Kumar, M.S. Production, optimization and partial purification of cellulase by Aspergillus niger fermented with paper and timber sawmill industrial wastes. Journal of Microbiology and Biotechnology Research v. 2, p. 120-128, 2012.

Doi, R.; Kosugi, A. Cellulosomes: plant cell walls degrading enzyme complexes. Nat Rev Microbiol. v. 2, p. 541-551, 2004.

Enari, T.M. Microbial Cellulases. Applied Science Publishers Ltd., London. p. 183$223,1983$.

Fukumori, F.; Kudo, T.; Horikoshi, K. Purification and Properties of a cellulase from Alkalophilic Bacillus sp. No 1139. Journal of General Microbiology. v. 131, p. 3339-3345, 1985.

Gaur R, Tiwari, S. 2015. Isolation, production, purification and characterization of an organic-solventthermostable alkalophilic cellulase from Bacillus vallismortis RG-07. BioMed Central Biotechnology 15:19.

Gautam SP, Bundela PS, Pandey AK, Awasthi MK, Sarsaiya S. 2010. Screening of cellulolytic fungi for management of municipal solid waste. Journal of Applied Science of the Environment. 4: 391-395.

Gokhan-Coral G, Burhan AN, Naldi M, Hatice GV. 2002. Some properties of crude carboxymethyl cellulase of Aspergillus niger Z10 Wild-Type strain. Turkish Journal of Biology 26: 209-213.

Gomathi C, Muthulakshmi C, Guru Kumar D, Ravikumar G, Kalaiselvi M, Uma C. 2012. Submerged fermentation of wheat bran by Aspergillus flavus for production and characterization of carboxymethyl cellulase. Asian Pacific Journal of Tropical Biomedicine 2(1): 67-73.

Gupta R, Gigras P, Mohapatra H, Goswami VK, Chauhan B. 2003. Microbial a-amylases. A Biotechnological Perspective. Process Biochemistry 38 (11): 1599-1616.

Gusakov AV, Salanovich TN, Antonov Al, Ustinov BB, Okunev ON, Burlingame R, Emalfarb M, Baez M, Sinitsyn AP. 2007. Design of Highly Efficient Cellulase Mixtures. Wiley Inter-Science 97(5): 10281038.

Haltrich D, Nidetzky B, Kulbe KD, Steiner W, Zupancic S. 1996. Production of fungal xylanases. Bioresource Technology 58: 137-161.

Howard RL, Abotsi E, Jansen REL, Howard S. 2003. Lignocellulose Biotechnology: Issue of Bioconversion and Enzyme Production. African Journal of Biotechnology. 2: 602-619.

ljaz A, Anwar Z, Irshad M, Iqbal Z, Arshad M, Javed M, Ahmad Z, Rehman A, Ahmad A. 2014. Purification and Kinetic Characterization of Statistically Optimized Cellulase Produced from Aspergillus niger. Romanian Biotechnological Letters 19(6):9835-9845. 
Ishida N, Okubo A, Kawai H, Yamazaki S, Toda S. 1980. Interaction of amino acids with transition metal ions in solution (I) solution structure of L-lysine with $\mathrm{Co}$ (II) and Cu (II) ions as studied by nuclear magnetic resonance spectroscopy. Agricultural and Biological Chemistry 44: 263-270.

James CC, Natalie S. 2001. Microbiology- A Laboratory Manual (Ed.). pp. 211-223.

Kasana RC, Salwan R, Dhar H, Dutt S, Gulati A. 2008. A rapid and easy method for the detection of microbial cellulases on agar plates using Gram's iodine. Current Microbiology 57: 503-507.

Kawamori M, Takaymma K, Takasawa S. 1987. Production of cellulase by a thermophilic fungus Thermoascus aurantiacus, A-131. Agricultural and Biological Chemistry 51: 647-654.

Kheng PP, Omar IC. 2005. Xylanase Production by a Local Fungal Isolate, Aspergillus niger USMAI 1 via Solid State Fermentation Using Palm Kernel Cake (PKC) as Substrate. Songklanakarin. Journal of Science and Technology. 27: 325-336.

Kudanga T, Mwenje E. 2005. Extracellular cellulase production by tropical isolates of Aureobasidium pullulans. Canadian Journal of Microbiology 51: 773-776.

Kumar D, Ashfaque M, Muthukumar M, Singh M, Garg N. 2012. Production and characterization of carboxymethyl cellulase from Paenibacillus sp. Journal of Environmental Biology. 33: 81-84.

Lakshmikant, K. and Mathur, S. N. (1990). Cellulolytic activities of Chaetomium globosumon different cellulosic substrates. World Journal of Bacteriology. 169(8): 3792-3800.

Li X, Yu HY. 2012. Purification and characterization of an organic solvent-tolerant alkaline cellulase from a halotolerant isolate, Bacillus sp. L1 Journal of Industrial Microbiology and Biotechnology 39(8): 11171124.

Lin H, Cheng W, Ding HT, Chen XJ, Zhou QF, Zhao YH. 2010. Direct Microbial Conversion of Wheat Straw into Lipid by a Cellulolytic Fungus of Aspergillus oryzae A-4 in Solid-State Fermentation. Bioresource Technology 101(19): 7556-7562.

Lineweaver H, Burk D. 1934. The Determination of Enzyme Dissociation Constants. Journal of the American Chemical Society 56(3): 658-666.

Lynd LR, Weimer PJ, Van ZyI WH, Pretorius IS. 2002. Microbial cellulose utilization: fundamentals and biotechnology. Microbiology and Molecular Biology Reviews. 66 (3): 506-577.

Mandels M, Hontz L, Nystron J. 1974. Enzymatic hydrolysis of waste cellulose. Biotechnology and Bioengineering 16: 147-1493.

Mandels M, Reese ET. 1965. Inhibition of cellulases. Annual Review of Phytopathology 3: 85-102. 
Mandels M, Reese ET. 1985. Fungal cellulose and microbial decomposition of cellulosic fibers. Industrial Microbiology 5: 5-20.

Mandels M. 1982. Cellulases. Annual Reports on Fermentation Processes 5: 35-78.

Miller GL. 1959. Use of Dinitrosalicyclic Reagent in Determination of Reducing Sugars. Analytical Chemistry. 31(3): 426-428.

Mrudula S, Murugammal R. 2011. Production of Cellulase by Aspergillus niger under Submerged and Solid-State Fermentation using Coir Waste as a Substrate. Brazilian Journal of Microbiology 42: 11191127.

Nelson DL, Cox MM. 2004. Lehninger Principles of Biochemistry. 4th ed. New York: pp. 1119.

Ogwuche VA, Chilaka FC, Eze SOO, Anyanwu CU. 2012. Production and properties of fungal cellulase from native isolates using orange bagasse as carbon source. Plant Product Research Journal 16: 16-22.

Olanbiwoninu AA, Odunfa SA. 2016. Production of Cellulase and Xylanase by Aspergillus terreus KJ829487 Using Cassava Peels as Subtrates. Advanced Microbiology 6: 502-511.

Otajevwo FD, Aluyi HSA. 2010. Cultural conditions necessary for optimal cellulase yield by cellulolytic bacterial organisms as they relate to residual sugars released in broth medium. Nigerian Journal of Microbiology 24(1): 2168-2182.

Padmavathi T, Vaswati N, Agarwal P. 2012. Optimization of the medium for production of cellulases by Aspergillus terreus and Mucor plumbeus. European Journal of Experimental Biology 2(4): 1161-1170.

Pandey A, Szakacs G, Soccol CR, Rodriguez-Leon JA, Soccol VT. 2001. Production, purification and properties of microbial phytases. Bioresource Technology 77(3): 203-214.

Potprommanee L, Wang X-Q, Han Y-J, Nyobe D, Peng Y-P, Huang Q. 2017. Characterization of a thermophilic cellulase from Geobacillus sp. HTA426, an efficient cellulase- producer on alkali pretreated of Lignocellulosic biomass. PLoS ONE 12(4): e0175004.

Quadri HO, Ademakinwa AN, Adejumo AL, Agboola FK. (2017). Partial purification and characterization of cellulolytic enzyme from Bacillus pantothenticus isolated from a Dumpsite. Research and Reviews: Journal of Microbiology and Biotechnology 6(2): 4-11.

Riordan JF. 1977. The role of metals in enzyme activity. Annual Clinical Laboratory Science 7: 119-129.

Roth JCG, Hoeltz M, Benitez LB, (2020). Current approaches and trends in the production of microbial cellulases using residual lignocellulosic biomass: a bibliometric analysis of the last 10 years. Arch Microbio/ 202, 935-951. https://doi.org/10.1007/s00203-019-01796-9 
Sabu A, Sarita S, Pandey A, Bogar B, Szakacs G, Socol CR. 2002. Solid-State Fermentation for Production of Phytase by Rhizopus oligosporus. Applied Biochemistry Biotechnology 103: 251-260.

Saha BC. 2004. Production, Purification and Properties of Endoglucanase from a Newly Isolated Strain of Mucor circinelloides. Process Biochemistry 39: 1871-1876.

Sajith S, Sreedevi S, Priji P, Unni KN, Benjamin S. 2014. Production and Partial Purification of Cellulase from a Novel Fungus, Aspergillus flavus BS1. Microbiology 64: 763-771.

Saleem M, Akhtar MS, Yasmin R, Zahid M, Malik NN, Afzal M, Rajoka MI. 2008. Production, Purification and Characterization of $\beta-1,4$-endoglucanase from a novel bacterial strain CTP-09 of Bacillus sp. Protein and Peptide Letters 15: 402-410.

Salihu A, Alam MZ. 2012. Production and applications of microbial lipases: A review. Scientific Research and Essays 7(30): 2667-2677.

Schnurer A, Jarvis A. 2010. Microbiological handbook for biogas plants. Swedish Waste Management U2009:03, Swedish Gas Centre Report 207: 1-74.

Seki Y, Kikuchi Y, Kimura Y, Yoshimoto R, Takahashi M, Aburai K, Kanai Y. 2015. Enhancement of cellulose degradation by cattle csaliva. PLoS One. 10(9): e0138902.

Sethi S, Gupta S. 2014. Optimization of cultural parameters for cellulose enzyme production from fungi. Biolife 2(3): 989-996.

Shahid ZH, Irfan M, Nadeem M, Syed Q, Qazi Jl. 2016. Production, Purification and Characterization of Carboxymethyl Cellulase from Novel Stain Bacillus megaterium. American Institute of Chemical Engineers pp.1-8.

Shankar T, Isaiarasu L. 2011. Cellulase production by Bacillus pumilus. EWBCM1 under varying cultural conditions. Middle-East Journal of Science Research 8: 40-45.

Sherief AA, El-Tanash AB, Atia N. 2010. Cellulase Production of Aspergillus fumigatus Grown on Mixed Substrate of Rice Straw and Wheat Bran. Research Journal of Microbiology. 5: 199-211.

Silva RC, Cotting LN, Poltronien TP, Balcao VM, De Almeida DBG, Goncalves LA, Grimaldi R, Gioelli LA. 2009. The Effects of Enzymatic Inter-esterification on the Physical Chemical Properties of Blends of Lard and Soybean Oil. LWT-Food Science and Technology 42: 1275- 1282.

Subramaniyan S, Prema P. 2004. Biotechnology of microbial xylanases: Enzymology, Molecular Biology and Application. Critical Reviews in Biotechnology. 22: 33-64.

Tejirian A, Xu F. 2010. Inhibition of cellulase-catalyzed lignocellulosic hydrolysis by iron and oxidative metal ions and complexes. Applied Environmental Microbiology 76: 7673-7682. 
Thapa S, Mishra J, Arora N. 2020. Microbial cellulolytic enzymes: diversity and biotechnology with reference to lignocellulosic biomass degradation. Rev Environ Sci Biotechnol. https://doi.org/10.1007/s11157-020-09536-y

Tokuda G, Watanabe H. 2007. Hidden cellulases in termites: revision of an old hypothesis. Biology Letters 3: 336-339.

Watanabe H, Tokuda G. 2001. Animal Cellulases. Cell Molecular Life Sciences. 58: 1167-1178.

Weber K, Osborn M. 1975. Proteins and Sodium dodecyl sulfate: Molecular weight determination on polyacrylamide gels and related procedures. In: The Proteins. Academic Press, New York. pp. 179-223.

Wood TM, Bhat KM. 1988. Methods for measuring cellulase activities. Methods in Enzymology 160: 87112.

Wood TM. 1992. Fungal cellulases. Biochemical Society Transactions. 20: 46-52.

Wu J, Ju LK. 1998. Enhancing enzymatic saccharification of waste newsprint by surfactant addition. Biotechnology Progress 14: 649-652.

Zaks A, Klibanov AM. 1988. Enzymatic catalysis in non-aqueous solvents. Journal of Biological Chemistry 263(7): 3194-3201.

Zhang YHP, Lynd LR. 2004. Toward an aggregated understanding of enzymatic hydrolysis of cellulose: Non-complexed cellulase systems. Biotechnology and Bioengineering. 88 (7): 797-824.

\section{Tables}

\section{Table 1a: Preliminary Screening of Fungi Isolates for Cellulase Production}




\begin{tabular}{|lll|}
\hline Fungal Isolates & Cellulase Activity & Halozone Diameter (Cm) \\
\hline Aureobasidium pullulans & + & 1.5 \\
\hline Rhizopus japonicas & - & 0.0 \\
\hline Aspergillus fumigatus & + & 3.0 \\
\hline Mucor ramannianus & + & 7.2 \\
\hline Trichoderma sp. & - & 0.0 \\
\hline Clonostachys rosea & + & 3.0 \\
\hline Rhizopus oryzae & + & 0.4 \\
\hline Aspergillus flavus & + & 4.6 \\
\hline Rhizopus stolonifer & - & 0.0 \\
\hline
\end{tabular}

Table $1 \mathrm{~b}$ : Extracellular cellulolytic activity in the basal medium by some selected isolates.

\begin{tabular}{|lll|}
\hline S/Ns Isolate Code & Identity of Isolates & Cellulase Activity (U/mg) \\
\hline $\mathrm{B}_{3}$ & Aureobasidium pullulans & 130.42 \\
$\mathrm{~B}_{5}$ & Mucor ramannianus & 156.81 \\
$\mathrm{C}_{6}$ & Clonostachys roseaf & 17.08 \\
\hline $\mathrm{D}_{1}$ & Rhizopus oryzae & 25.22 \\
\hline $\mathrm{D}_{2}$ & Aspergillus flavus & 116.96 \\
\hline
\end{tabular}

Table 2: Summary of the Purification of Cellulase from Mucor ramannianus.

\begin{tabular}{|llllll|}
\hline $\begin{array}{l}\text { Purification } \\
\text { Step }\end{array}$ & $\begin{array}{l}\text { Total Activity } \\
(\mathrm{U})\end{array}$ & $\begin{array}{l}\text { Total Protein } \\
(\mathrm{mg})\end{array}$ & $\begin{array}{l}\text { Specific Activity } \\
(\mathrm{U} / \mathrm{mg})\end{array}$ & $\begin{array}{l}\text { Yield } \\
(\%)\end{array}$ & Fold \\
\hline Crude Enzyme & 598 & 0.42 & 1423 & 100 & 1.0 \\
\hline $\begin{array}{l}\text { Gel filtration on } \\
\text { Sephacryl S- }\end{array}$ & 271 & 0.12 & 2214 & 46 & 2.0 \\
200 & & & & & \\
\hline
\end{tabular}


Table 3: Biodegradation of agroindustrial waste by the partially purified $M$. ramannianus cellulase

\begin{tabular}{|l|l|}
\hline Substrate & $\begin{array}{l}\text { Reducing Sugar Equivalent } \\
(\mu \mathrm{g} \text { glucose/g of substrate })\end{array}$ \\
\hline Carboxymethyl cellulose & $1.2 \pm 0.2$ \\
\hline Cellobiose & $2.1 \pm 0.2$ \\
\hline Orange peel flour & $3.4 \pm 0.3$ \\
\hline Orange bagasse flour & $2.9 \pm 0.4$ \\
\hline Cassava peel flour & $1.8 \pm 0.3$ \\
\hline Pineapple peel flour & $2.3 \pm 0.8$ \\
\hline Potato peel flour & $1.6 \pm 0.6$ \\
\hline Banana peel flour & $2.0 \pm 0.2$ \\
\hline Plantain peel flour & $2.5 \pm 0.5$ \\
\hline
\end{tabular}

Figures

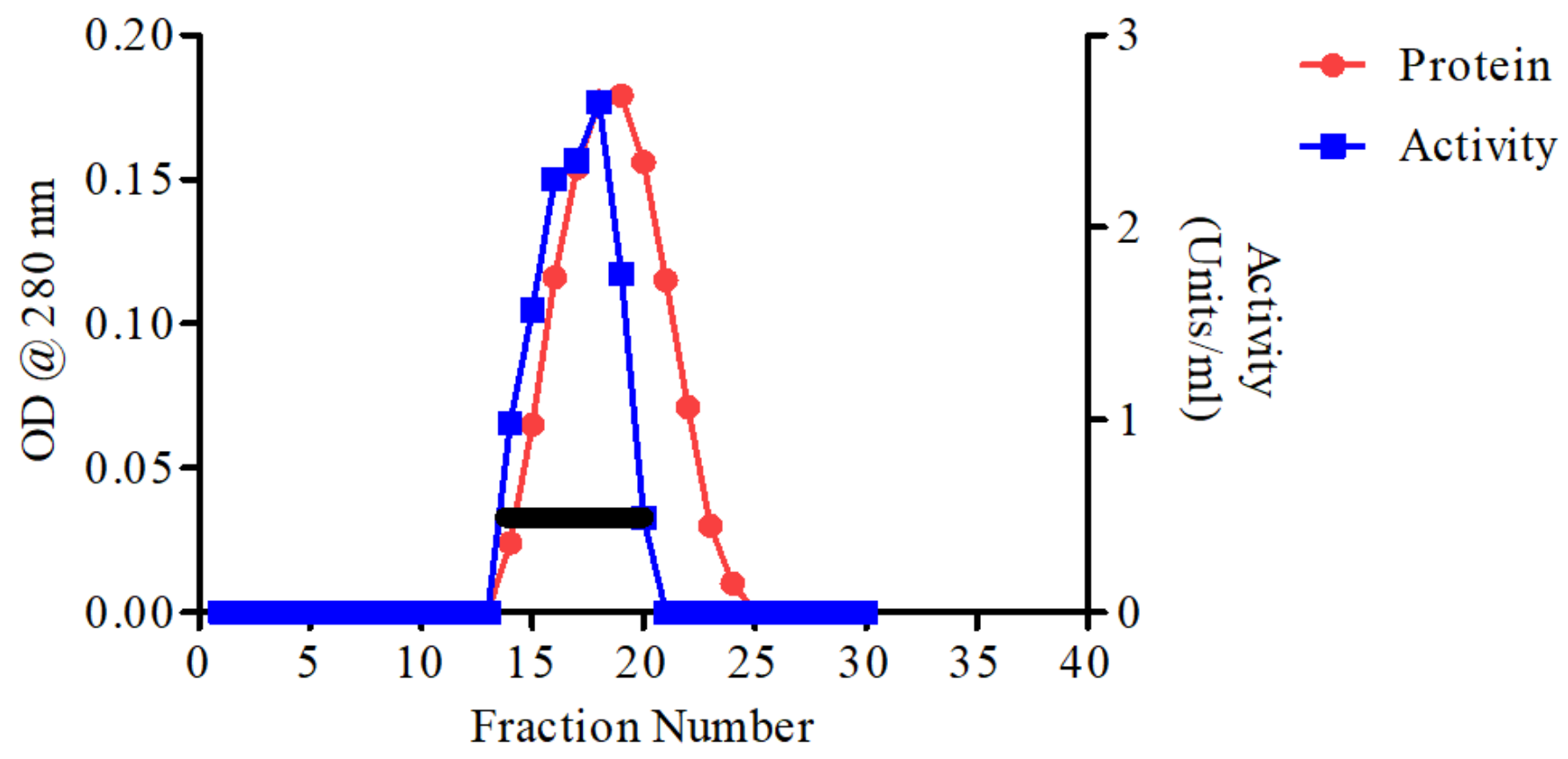

Figure 1 
Elution Profile of Cellulase from Mucor ramannianus on Sephacryl S-200. The column was equilibrated with $0.1 \mathrm{M}$ Citrate buffer, $\mathrm{pH}$ 4.8. Fractions of $5 \mathrm{ml}$ were collected from the column at a flow rate of $20 \mathrm{ml} /$ hour.

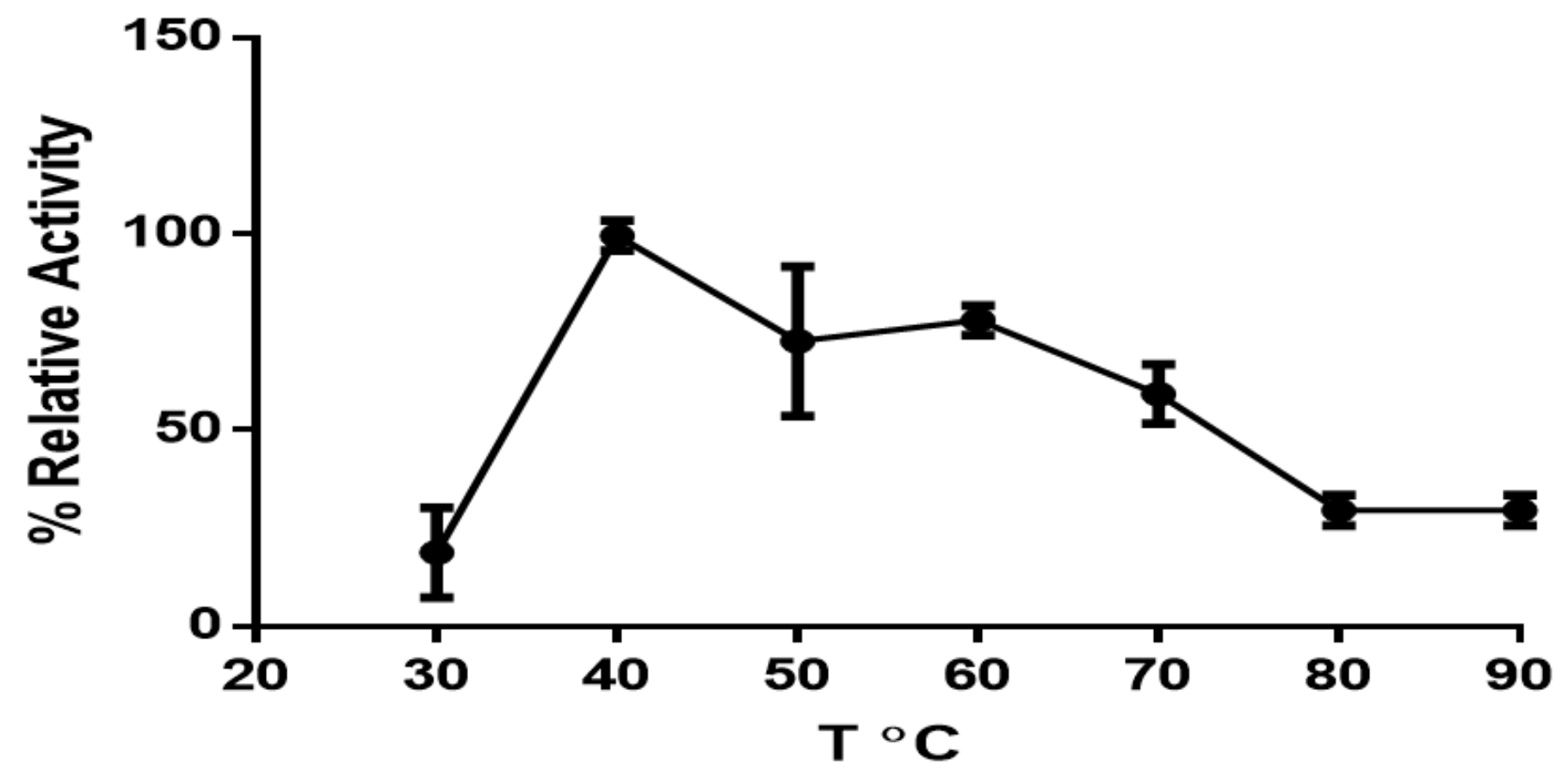

Figure 2

Effect of Temperature on Activity of Cellulase from Mucor ramannianus. The values shown represent the average from triplicate experiments. Error bars represent the standard deviation. 


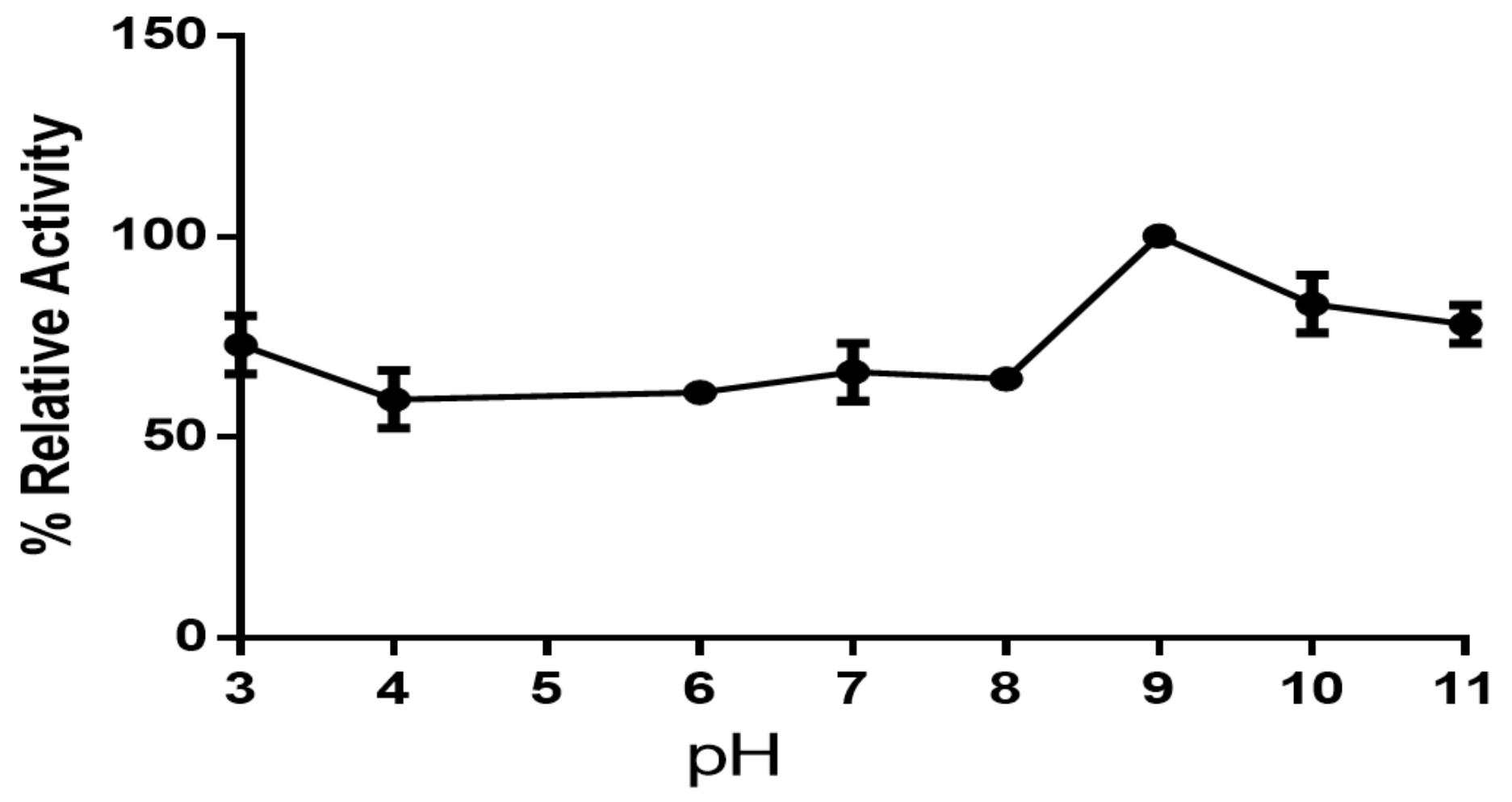

Figure 3

Effect of $\mathrm{pH}$ on Activity of Cellulase from Mucor ramannianus. Optimum $\mathrm{pH}$ was obtained using $50 \mathrm{mM}$ Acetate buffer (pH 3.0-5.0), $50 \mathrm{mM}$ Citrate buffer ( $\mathrm{pH}$ 4.0-6.0), mM Tris buffer (pH 7.0-9.0) and $50 \mathrm{mM}$ Borate buffer ( $\mathrm{pH}$ 9.0-11.0).

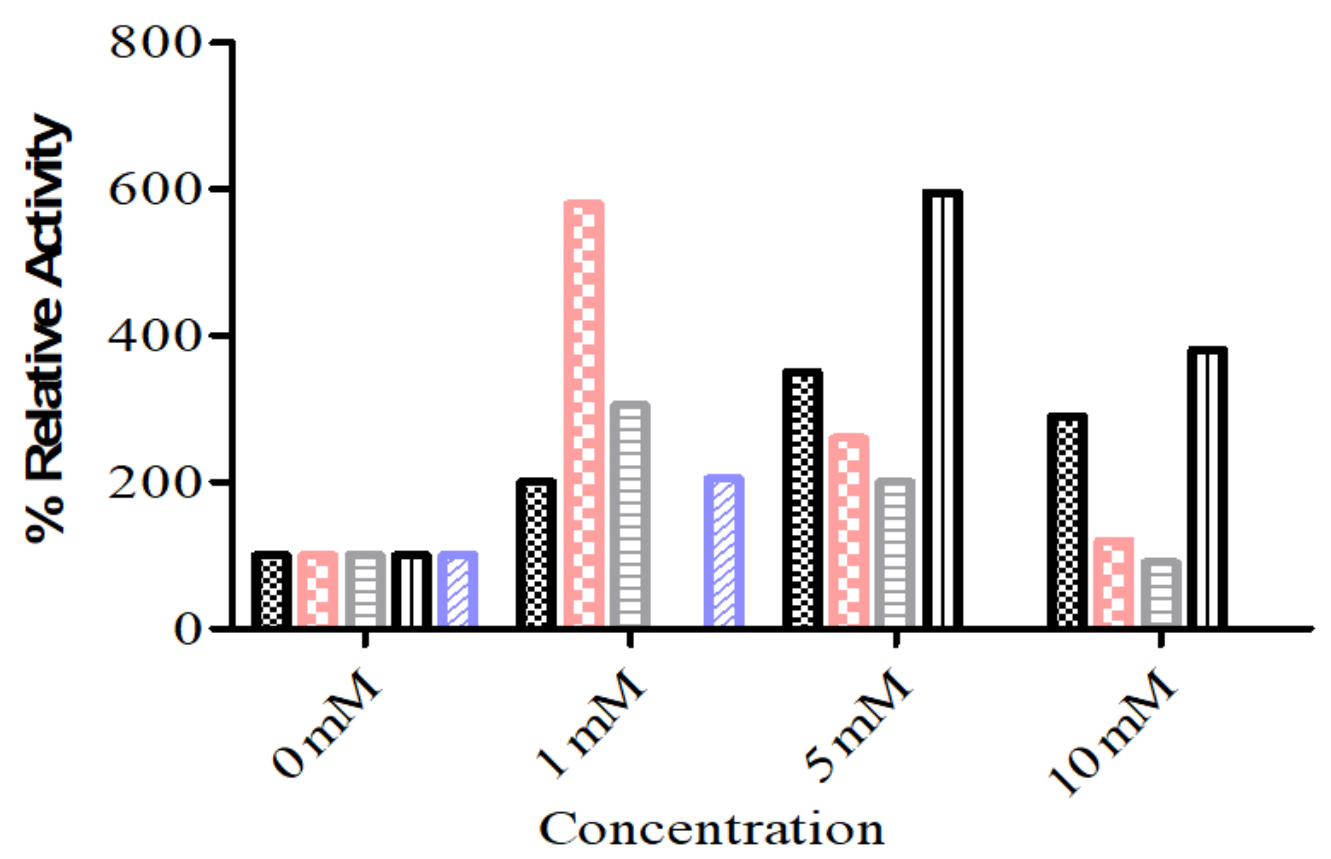

E\$ $\mathrm{NaCl}$

$\mathrm{KCl}$

$\mathrm{HgCl}$

एण $\mathrm{CaCl}_{2}$

$\mathrm{BaCl}_{2}$

Figure 4 
Effect of Salts on Activity of Cellulase from Mucor ramannianus. The relative activity was determined by measuring cellulase activity in the control that contained no chloride salt and taken as $100 \%$. The values shown represent the average from triplicate experiments.

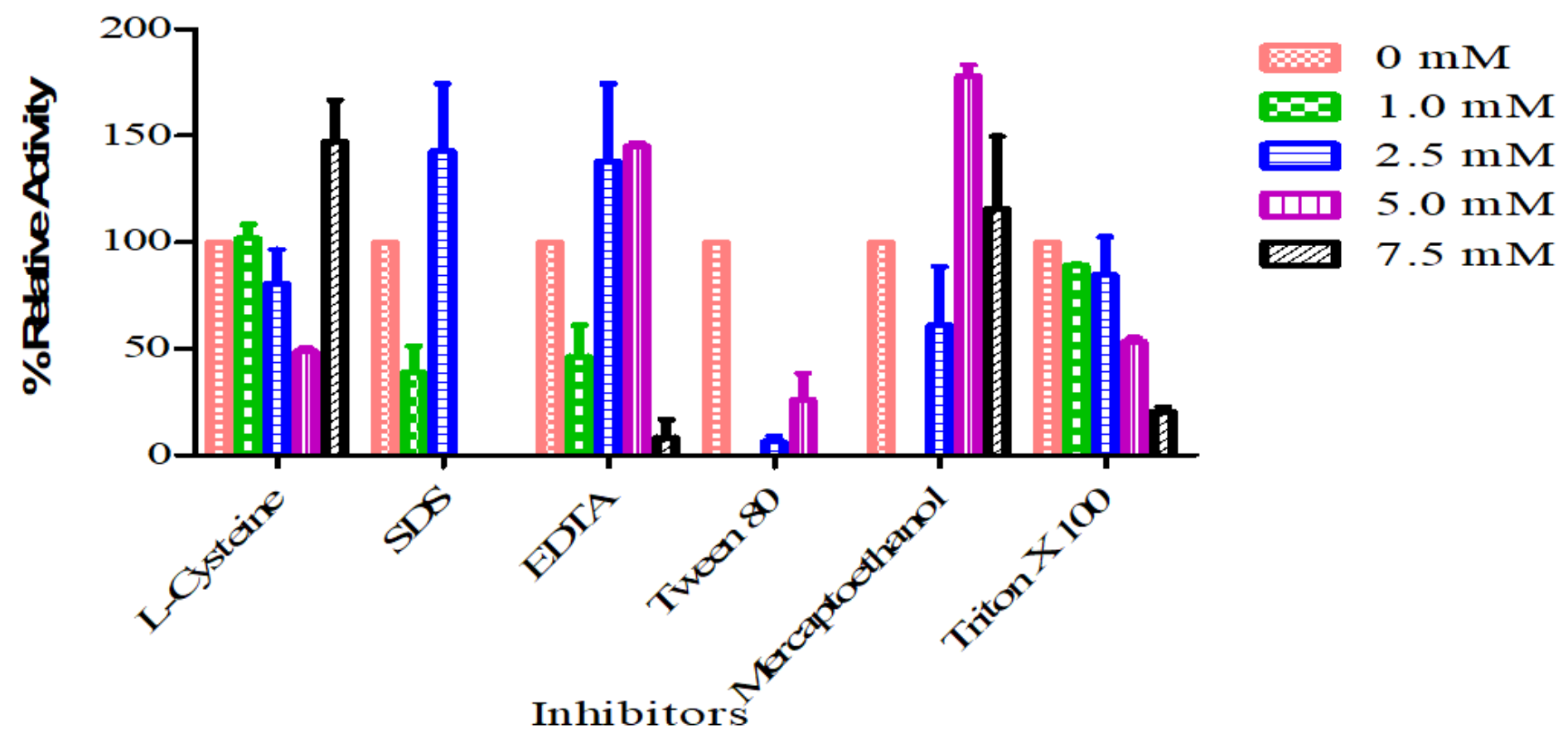

\section{Figure 5}

Effect of Inhibitors on Activity of Cellulase from Mucor ramannianus. The relative activity was determined by measuring cellulase activity in the control that contained inhibitor and taken as $100 \%$. The values shown represent the average from triplicate experiments. 


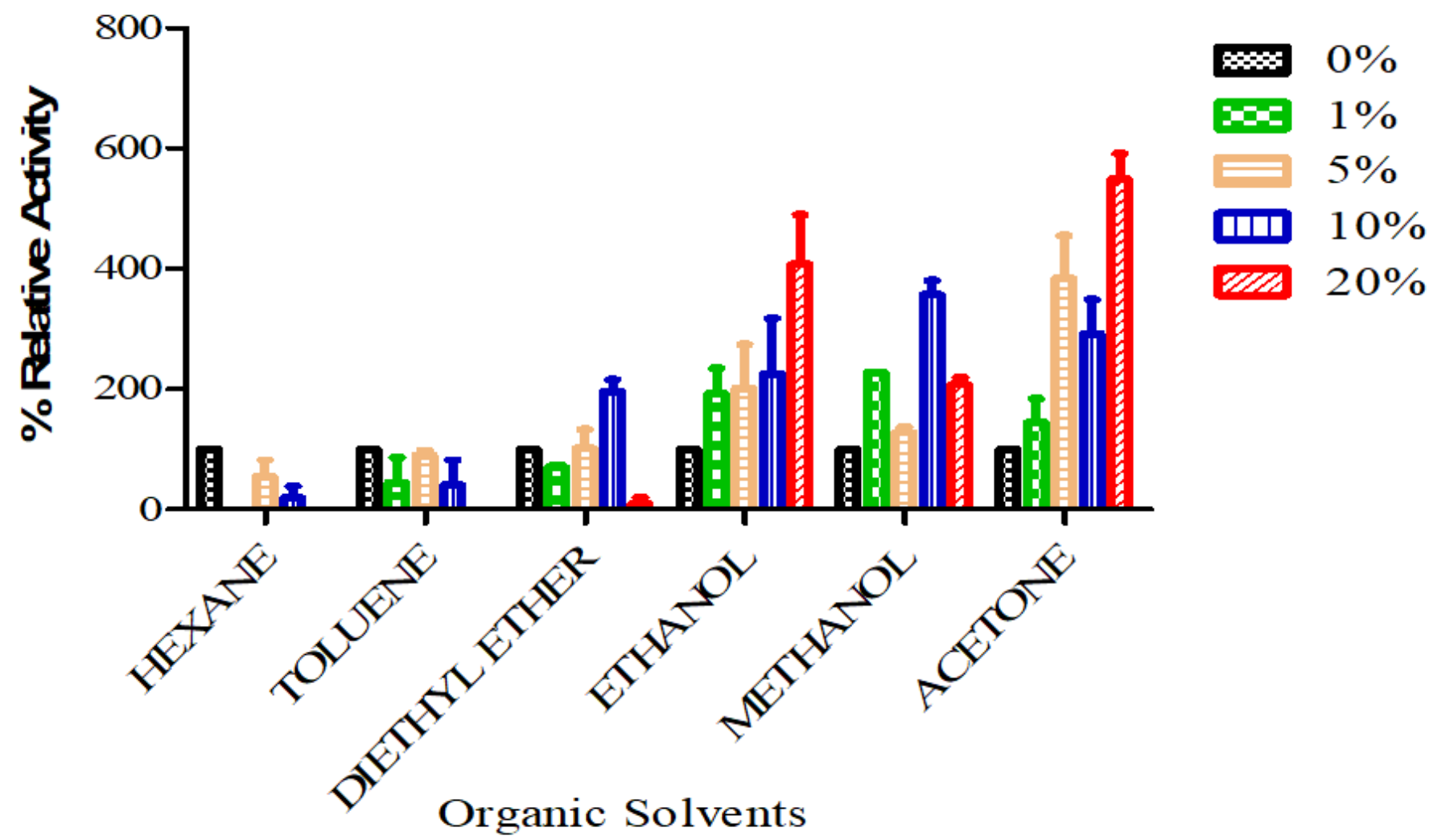

Figure 6

Effect of Organic Solvents on Activity of Cellulase from Mucor ramannianus. The relative activity was determined by measuring cellulase activity in the control that contained no inhibitor and taken as $100 \%$. The values shown represent the average from triplicate experiments. 


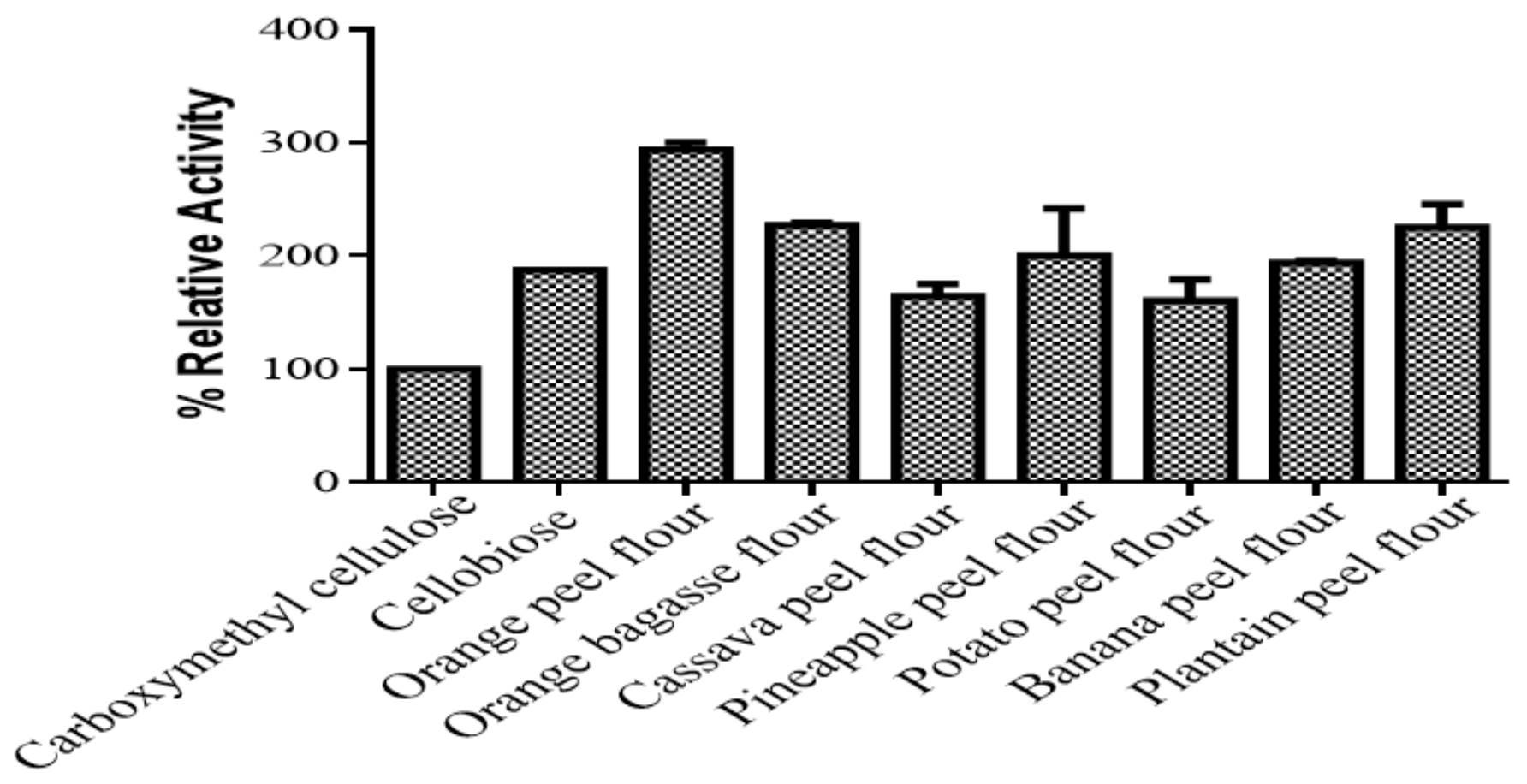

Substrates

Figure 7

M. ramannianus cellulase activities with various natural substrates. The values shown represent the average from triplicate experiments. 